\title{
Diversity and New Records of Polychaetes (Annelida) in the Sinop Peninsula, Turkey (Southern Black Sea)
}

\author{
Mulkibar Ciftcioglu ${ }^{10}$, Guley Kurt ${ }^{2}$ (D), Sevgi Kus ${ }^{3}$ (D) \\ 'Muğla Sıtkı Koçman University, Institute of Natural and Applied Sciences, Muğla, Turkey \\ ${ }^{2}$ Sinop University, Faculty of Arts and Sciences, Department of Biology, Sinop, Turkey \\ ${ }^{3}$ Sinop University, Institute of Natural and Applied Sciences, Sinop, Turkey
}

ORCID IDs of the authors: M.C. 0000-0001-7521-8969; G.K. 0000-0002-9996-4365; S.K. 0000-0002-3336-3444

Please cite this article as: Ciftcioglu M, Kurt G, Kus S. Diversity and New Records of Polychaetes (Annelida) in the Sinop Peninsula, Turkey (Southern Black Sea). Eur J Biol 2020; 79(2): 106-114. DOI: 10.26650/EurJBiol.2020.0024

\begin{abstract}
Objective: This study determines the diversity of annelid polychaete species distributed around the coast of Sinop and to identify possible spatial and temporal variations of the Polychaeta community.

Materials and Methods: Benthic material was collected from 8 stations using Van Veen grab between October 2013 and July 2014 on the soft bottom of Sinop Peninsula.

Results: A total of 90 species belonging to 30 families were identified. Among them, Galathowenia cf. oculata, Rhodine loveni Malmgren, 1865, Paradoneis armata Glémarec, 1966, Paralacydonia paradoxa Fauvel, 1913 and Syllis cf. amica are new records for the Black Sea fauna and Glycera tridactyla Schmarda, 1861 is new for the Turkish coast of the Black Sea. Prionospio (Minuspio) maciolekae Dagli and Çinar, 2011, Micronephthys longicornis (Perejaslavtseva, 1891) and Protodorvillea kefersteini (Mclntosh, 1869) were the most frequent and dominant species in the study area. The highest mean number of species (29 species) was found in spring at station G2; the lowest mean number of species (4 species) was determined at station G3 in winter. The highest mean density value (9470 ind. $\left.\mathrm{m}^{-2}\right)$ was determined at $\mathrm{G} 2$ station in summer; the lowest mean density value ( 357 ind. $\mathrm{m}^{-2}$ ) was calculated in autumn at station $\mathrm{G} 5$.
\end{abstract}

Conclusion: The Polychaeta diversity on the soft bottom of the Sinop Peninsula was analyzed and four species were newly recorded for the Black Sea fauna and one for the Turkish Black Sea fauna.

Keywords: Polychaeta, benthos, community, diversity, density

\section{INTRODUCTION}

Annelid polychaetes are the most diverse benthic invertebrates and they densely occur on the sea-floor. Although most of the polychaetes live in a marine environment, fresh and brackish water forms are also known. Up to date, more than 12,000 species of Polychaeta have been reported in the world oceans (1); from them, more than 1,100 species have been reported in the Mediterranean Sea (2). Nowadays, a total of 711 species have been reported on the coast of Turkey with 459 species in the Levantine Sea, 559 species in the Aegean Sea, 398 species in the Sea of Marmara, and 187 in the Black Sea (3-7).
Sinop Peninsula is located on the Black Sea with a salinity of about $18 \%$. The Black Sea is one of the largest semi-closed seas in the world with an area of approximately $4.2 \times 105 \mathrm{~km}^{2}$, an average depth of $2,212 \mathrm{~m}$, and a water volume of $534,000 \mathrm{~km}$ (8). Due to the high rate of hydrogen sulphide $\left(\mathrm{H}_{2} \mathrm{~S}\right)$, most of the Black Sea basin ( 87\%) shows anoxic properties $(8,9)$. Anoxic conditions affect the vertical distribution of organisms at depths below 70-200 meters. The hydrographic regime is characterized by high salinity in the deep waters of the Mediterranean origin, which is covered by the low salinity surface waters of the river. 
The structure of the Black Sea ecosystem differs from the Mediterranean because of less diversity and dominant groups of species. However, productivity, total biomass and abundance values of the Black Sea are higher than those of the Mediterranean Sea $(5,9)$.

There are only a few investigations on polychaete diversity from the Black Sea (10-16). All the studies that addressed the Turkish Black Sea have focused on the pyrophosphoric region, (17-24) and some others on the Anatolian coasts (5-7, 25-28).

Hence, the aims of this study are to assess diversity of polychaetes in the soft bottoms of the Sinop Peninsula and to determine temporal and spatial variations in the community of polychaetes.

\section{MATERIALS AND METHODS}

Samplings were conducted between October 2013 and July 2014 to identify diversity and seasonal changes of polychaete species along the coast of Sinop. Benthic samples were collected seasonally from soft substratum using a Van Veen grab at 8 stations, each with 3 replicates (Figure 1; Table 1). The material was sieved on board by using a $0.5 \mathrm{~mm}$ mesh sieve, and seawater for dilution. The organisms were fixed with $4 \%$ formaldehyde and placed in containing plastic bags. In the laboratory, the fixed material was washed off with tap water using a $0.5 \mathrm{~mm}$ mesh and sorted into major taxonomic groups using a light and stereomicroscope and each sample was preserved into tubes containing $70 \%$ ethanol. Polychaetes were determined at species level, although those undetermined were kept at genus level, and the numbers of individuals were counted. The material was deposited in the Hydrobiology Laboratory of the Biology Department of Sinop University, Turkey.

The following biotic indices were used to assess the structure of polychaete communities in the research area: Dominance Index of Bellan-Santini (29), Shannon-Wiener's diversity index $\left(H^{\prime}\right)$, Pielou's evenness index $\left(J^{\prime}\right)$ and, Soyer's frequency index (30). All were performed by using PRIMER 5 and STATISTICA 7.0.

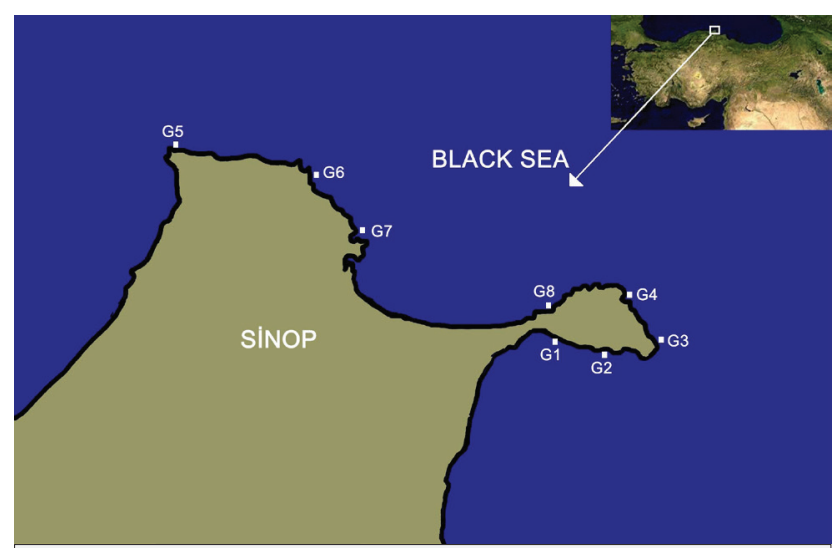

Figure 1. Sampling stations at Sinop Peninsula, Turkey (Black Sea).
The identified species were also classified according to the ecological groups mentioned by Çınar et al. (31). The first ecological group includes sensitive and insensitive species (GI and GII), the second ecological group includes tolerant species (GIII), and the third ecological group includes first and second order opportunistic species (GIV and GV) (31).

Table 1. Coordinates, depth, and sediment type of sampling stations at Sinop Peninsula.

\begin{tabular}{|c|c|c|c|}
\hline Station & Coordinates & Depth (m) & Sediment type \\
\hline \multirow[t]{2}{*}{ G1 } & $42^{\circ} 02^{\prime} 030$ " N & \multirow[t]{2}{*}{14} & \multirow{2}{*}{$\begin{array}{l}\text { Mud and shell } \\
\text { fragments }\end{array}$} \\
\hline & $35^{\circ} 15^{\prime} 060$ " E & & \\
\hline \multirow[t]{2}{*}{$\mathrm{G} 2$} & $42^{\circ} 01^{\prime} 329^{\prime} \mathrm{N}$ & \multirow[t]{2}{*}{15} & \multirow{2}{*}{$\begin{array}{l}\text { Mud and shell } \\
\text { fragments }\end{array}$} \\
\hline & $35^{\circ} 18$ ' 371 " E & & \\
\hline \multirow[t]{2}{*}{ G3 } & $42^{\circ} 02^{\prime} 166^{\prime \prime} \mathrm{N}$ & \multirow[t]{2}{*}{20} & \multirow[t]{2}{*}{ Fine sand } \\
\hline & $35^{\circ} 21^{\prime} 077^{\prime} \mathrm{E}$ & & \\
\hline \multirow[t]{2}{*}{ G4 } & $42^{\circ} 03^{\prime} 804^{\prime \prime} \mathrm{N}$ & \multirow[t]{2}{*}{21} & \multirow[t]{2}{*}{ Fine sand } \\
\hline & $35^{\circ} 19^{\prime} 353^{\prime \prime} \mathrm{E}$ & & \\
\hline \multirow[t]{2}{*}{ G5 } & $42^{\circ} 09^{\prime} 936^{\prime} \mathrm{N}$ & \multirow[t]{2}{*}{14} & \multirow[t]{2}{*}{ Silt } \\
\hline & $34^{\circ} 94^{\prime} 968^{\prime} \mathrm{E}$ & & \\
\hline \multirow[t]{2}{*}{ G6 } & $42^{\circ} 08^{\prime} 497$ " N & \multirow[t]{2}{*}{20} & \multirow{2}{*}{$\begin{array}{c}\text { Fine sand, mud and } \\
\text { shell fragments }\end{array}$} \\
\hline & $35^{\circ} 02^{\prime} 176^{\prime \prime} \mathrm{E}$ & & \\
\hline \multirow[t]{2}{*}{ G7 } & $42^{\circ} 06^{\prime} 300$ " N & \multirow[t]{2}{*}{20} & \multirow{2}{*}{$\begin{array}{l}\text { Sand, Fine sand and } \\
\text { Mud }\end{array}$} \\
\hline & $35^{\circ} 04^{\prime} 548^{\prime \prime} \mathrm{E}$ & & \\
\hline \multirow[t]{2}{*}{ G8 } & $42^{\circ} 03^{\prime} 121^{\prime \prime} \mathrm{N}$ & \multirow[t]{2}{*}{14} & \multirow[t]{2}{*}{ Sand } \\
\hline & $35^{\circ} 15^{\prime} 344^{\prime \prime} E$ & & \\
\hline
\end{tabular}

\section{RESULTS}

A total of 90 species belonging to 30 families and 63 genera were determined in the study area (Table 2). Galathowenia cf. oculata, Rhodine loveni Malmgren 1865, Paradoneis armata Glémarec, 1966, Paralacydonia paradoxa Fauvel, 1913 and Syllis cf. amica were new records for the Black Sea fauna and Glycera tridactyla Schmarda, 1861 was a new record for the Turkish coast of the Black Sea.

According to frequency index values, 40 species were distributed as constant $(50<\mathrm{F} \leq 100), 15$ as common $(25>\mathrm{F} \leq 50)$, and 35 species as rare $(0>\mathrm{F} \leq 25)$ (Table 2). Among them, Micronephthys longicornis, Prionospio maciolekae, Spio decoratus, Heteromastus filiformis and Melinna palmata were found at all stations (100\%). Syllidae (13 species) was the most diverse family in the area, followed by Spionidae ( 8 species), Paraonidae ( 8 species) and Nereididae (7 species). According to the number of individuals, the most dominant families were identified as Spionidae, Nephtyidae and Dorvilleidae, and these families were found during all sampling periods. The most dominant species were $P$. maciolekae, $M$. longicornis, P. kefersteini, H. filiformis and S. decoratus. 
Table 2. List of species collected during the study and their maximum densities (ind. $\mathrm{m}^{-2}$ ) per station (A: autumn, W: winter, Sp: spring, S: summer, F: Frequency values (\%)).

\begin{tabular}{|c|c|c|c|c|c|c|c|c|c|}
\hline Species & G1 & G2 & G3 & G4 & G5 & G6 & G7 & G8 & $\mathbf{F}$ \\
\hline \multicolumn{10}{|l|}{ Ampharetidae } \\
\hline $\begin{array}{l}\text { Melinna palmata Grube, } \\
1870\end{array}$ & $80 / \mathrm{Sp}$ & $100 / S$ & $290 / S p$ & $510 / S p$ & $440 / S$ & $330 / \mathrm{W}$ & $1120 / W$ & $300 / S$ & 100 \\
\hline \multicolumn{10}{|l|}{ Capitellidae } \\
\hline Capitella cf. capitata & $60 / \mathrm{W}$ & - & $10 / \mathrm{Sp}$ & $10 / \mathrm{S}$ & $20 / 5$ & $30 / \mathrm{sp}$ & $140 / \mathrm{Sp}$ & $20 / S p-S$ & 87.5 \\
\hline $\begin{array}{l}\text { Capitomastus } \\
\text { minima (Langerhans, 1881) }\end{array}$ & - & - & $150 / \mathrm{Sp}$ & - & - & $120 / S p$ & $10 / \mathrm{W}-\mathrm{S}$ & $250 / \mathrm{W}$ & 50 \\
\hline $\begin{array}{l}\text { Heteromastus filiformis } \\
\text { (Claparède, 1864) }\end{array}$ & 950/Sp & $730 / S p$ & $10 / \mathrm{A}-\mathrm{Sp}$ & $390 / \mathrm{W}$ & $50 / \mathrm{Sp}$ & 870/W & $340 / W$ & $50 / \mathrm{Sp}$ & 100 \\
\hline Mediomastus sp. & - & - & 10/Sp & - & - & - & $60 / S$ & - & 25 \\
\hline $\begin{array}{l}\text { Notomastus latericeus Sars, } \\
1851\end{array}$ & $690 / \mathrm{Sp}$ & $570 / S$ & 10/Sp & 190/W & $60 / S p$ & $110 / \mathrm{W}$ & $80 / S p-W$ & - & 87.5 \\
\hline Notomastus sp. & $130 / A$ & $20 / \mathrm{S}$ & - & $10 / \mathrm{A}$ & - & - & $10 / \mathrm{S}$ & - & 50 \\
\hline \multicolumn{10}{|l|}{ Cirratulidae } \\
\hline Chaetozone sp. & 10/Sp & - & - & $10 / A$ & - & - & - & - & 25 \\
\hline $\begin{array}{l}\text { Cirriformia } \\
\text { tentaculata (Montagu, } \\
1808 \text { ) }\end{array}$ & - & - & - & $10 / A$ & - & - & - & - & 12.5 \\
\hline
\end{tabular}

\section{Dorvilleidae}

Dorvillea

rubrovittata (Grube, 1855)

Protodorvillea

kefersteini (Mclntosh, 1869)

Schistomeringos

rudolphi (Delle Chiaje, 1828)

\section{Eunicidae}

\begin{tabular}{lllll}
\hline Eunice vittata (delle Chiaje, & $90 / \mathrm{W}$ & $70 / \mathrm{S}$ & - & $20 / \mathrm{A}$
\end{tabular}

$10 / \mathrm{Sp} \quad 130 / \mathrm{W}$

1828)

Lysidice ninetta Audouin-

10/Sp-W

$570 / \mathrm{Sp} \quad 940 / \mathrm{Sp} \quad 540 / \mathrm{Sp} \quad 1810 / \mathrm{A}$

$4150 / A$

$2310 /$

Milne Edwards, 1833

\section{Glyceridae}

Glycera alba Grube, 1840

Glycera tesselata Grube, 1863

\begin{tabular}{|c|c|c|c|c|c|c|c|c|c|}
\hline $\begin{array}{l}\text { *Glycera } \\
\text { tridactyla Schmarda, } 1861\end{array}$ & $10 / S p$ & $10 / S p-W$ & - & $10 / \mathrm{S}$ & $50 / S p$ & $30 / S p$ & $10 / \mathrm{Sp}-\mathrm{S}$ & $10 / \mathrm{W}$ & 87.5 \\
\hline Glycera sp. & - & $20 / \mathrm{S}$ & - & $10 / \mathrm{A}$ & $80 / \mathrm{S}$ & $10 / S p$ & 10/W-S & 10/W-S & 75 \\
\hline \multicolumn{10}{|l|}{ Hesionidae } \\
\hline Microphthalmus sp. & $20 / S p$ & - & $60 / S p$ & $100 / \mathrm{A}$ & - & 90/W & 90/Sp-S & $10 / S p$ & 75 \\
\hline \multicolumn{10}{|l|}{ Lacydoniidae } \\
\hline $\begin{array}{l}\text { *Paralacydonia } \\
\text { paradoxa Fauvel, } 1913\end{array}$ & - & $10 / \mathrm{S}$ & - & - & - & - & $10 / S p$ & - & 25 \\
\hline
\end{tabular}

Lumbrineridae

Lumbrinereis sp. 
Tablo 2 (Continued)

\section{Magelonidae}

Magelona

mirabilis (Johnston, 1865)

10/Sp-W 30/Sp-W 170/S

310/

20/Sp-

100/

90/Sp-W

87.5

Maldanidae

Leiochone leiopygos (Grube, 10/Sp-W 1860)

*Rhodine loveni Malmgren,

$40 / \mathrm{Sp}$

$10 / \mathrm{Sp}$

Sp-W

W-S

Sp-W

1865

\section{Nephtyidae}

Micronephthys

4290/W $2570 / S p \quad 260 / S$

longicornis (Perejaslavtseva,

1891)

Nephtys hombergii Savigny

10/A 20/Sp

$10 / \mathrm{W}$

10/A-S 20/W

62.5

in Lamarck, 1818

\begin{tabular}{|c|c|c|c|c|c|c|c|c|c|}
\hline Nephtys sp. & - & - & $20 / \mathrm{W}$ & $40 / \mathrm{W}$ & 200/W & 90/W & 20/W & $130 / \mathrm{Sp}$ & 75 \\
\hline \multicolumn{10}{|l|}{ Nereididae } \\
\hline Ceratonereis sp. & - & $50 / \mathrm{S}$ & - & - & - & - & - & - & 12.5 \\
\hline $\begin{array}{l}\text { Eunereis } \\
\text { longissima (Johnston, 1840) }\end{array}$ & 20/W & $10 / \mathrm{Sp}$ & - & - & - & - & - & - & 25 \\
\hline Nereis cf. zonata & 20/A-Sp-S & $110 / \mathrm{S}$ & - & $10 / S$ & - & $10 / \mathrm{Sp}$ & - & - & 50 \\
\hline $\begin{array}{l}\text { Perinereis cultrifera (Grube, } \\
\text { 1840) }\end{array}$ & $170 / \mathrm{W}$ & $180 / \mathrm{A}$ & - & $70 / \mathrm{W}$ & - & $30 / \mathrm{W}$ & $10 / S p-W$ & - & 62.5 \\
\hline $\begin{array}{l}\text { Platynereis } \\
\text { dumerilii (Audouin-Milne } \\
\text { Edwards, 1833) }\end{array}$ & $90 / A$ & $80 / \mathrm{W}$ & - & $30 / A$ & - & $10 / A$ & $40 / A$ & - & 62.5 \\
\hline $\begin{array}{l}\text { Websterinereis } \\
\text { glauca (Claparède, 1870) }\end{array}$ & - & $10 / A$ & - & - & - & - & - & - & 12.5 \\
\hline Nereididae (sp.) & $60 / \mathrm{W}$ & $120 / S$ & $210 / S$ & $10 / A-S$ & - & - & $10 / A-W$ & - & 62.5 \\
\hline \multicolumn{10}{|l|}{ Opheliidae } \\
\hline $\begin{array}{l}\text { Polyophthalmus } \\
\text { pictus (Dujardin, 1839) }\end{array}$ & - & - & - & - & - & $10 / A$ & 10/W-Sp & - & 25 \\
\hline Orbiniidae & & & & & & & & & 75 \\
\hline $\begin{array}{l}\text { Phylo foetida (Claparède, } \\
\text { 1868) }\end{array}$ & - & - & - & $10 / A-W-S$ & $50 / S p$ & - & - & - & 25 \\
\hline \multicolumn{10}{|l|}{ Oweniidae } \\
\hline *Galathowenia cf. oculata & & $540 / \mathrm{Sp}$ & $10 / S$ & - & - & $10 / A$ & 40/W & - & 50 \\
\hline \multicolumn{10}{|l|}{ Paraonidae } \\
\hline $\begin{array}{l}\text { Aricidea (Acmira) catherinae } \\
\text { Laubier, } 1967\end{array}$ & $50 / A$ & 20/A-S & - & $450 / \mathrm{A}$ & $20 / S p$ & $200 / A$ & $80 / \mathrm{Sp}$ & $70 / \mathrm{Sp}$ & 87.5 \\
\hline $\begin{array}{l}\text { Aricidea (Strelzovia) } \\
\text { claudiae Laubier, } 1967\end{array}$ & $650 / S$ & $80 / \mathrm{W}$ & $20 / S p$ & $50 / \mathrm{S}$ & - & $10 / \mathrm{Sp}$ & - & $10 / \mathrm{Sp}$ & 75 \\
\hline $\begin{array}{l}\text { Aricidea (Aricidea) } \\
\text { pseudoarticulata Hobson, } \\
1972\end{array}$ & - & - & - & - & $10 / A$ & - & $20 / A$ & - & 25 \\
\hline $\begin{array}{l}\text { Aricidea (Acmira) } \\
\text { simonae Laubier \& Ramos, } \\
1974\end{array}$ & - & - & - & $10 / \mathrm{W}$ & - & - & - & 10/Sp & 25 \\
\hline
\end{tabular}


Tablo 2 (Continued)

Aricidea sp.

10/W

*Paradoneis

$-$

$10 / \mathrm{S}$

25

armata Glémarec, 1966

Paradoneis lyra (Southern,

$80 / \mathrm{Sp} \quad 10 / \mathrm{Sp}$

1914)

Paradoneis sp.

50/A

$10 / \mathrm{S}$

Pectinariidae

Lagis koreni Malmgren,

$70 / S p$

80/Sp

20/W

20/A

10/A-W

62.5

1866

\section{Pholoidae}

\begin{tabular}{llllllllllll}
\hline Pholoe inornata Johnston, & $170 / \mathrm{Sp}-$ & $320 / \mathrm{A}$ & $30 / \mathrm{Sp}$ & $450 / \mathrm{A}$ & - & $150 / \mathrm{Sp}$ & $530 / \mathrm{A}$ & -
\end{tabular}
1839 W

\section{Phyllodocidae}

Eumida cf. sanguinea

Mysta picta (Quatrefages, 1866)

Nereiphylla
rubiginosa (Saint-Joseph,
1888)

Phyllodoce (Anaitides) rosea (McIntosh, 1877)

Phyllodoce sp.

Pterocirrus

macroceros (Grube, 1860)

\section{Pilargidae}

\section{Sigambra}

tentaculata (Treadwell,

1941)

Sigambra sp.

20/W

$\begin{array}{ccccc}70 / \mathrm{W} & 160 / \mathrm{W} & 10 / \mathrm{Sp} & 20 / \mathrm{A}-\mathrm{W} & - \\ 20 / \mathrm{Sp} & 30 / \mathrm{Sp}-\mathrm{W} & 10 / \mathrm{S} & 20 / \mathrm{W} & -\end{array}$

$10 / \mathrm{Sp} \quad 30 / \mathrm{Sp}$

20/A-W

$20 / \mathrm{Sp}$

$10 / S$

40/A 20/A-Sp 20/W

$60 / \mathrm{W} \quad 40 / \mathrm{Sp} \quad 10 / \mathrm{sp}$

87.5

$50 / \mathrm{Sp}$

10/W

Pisionidae

Pisione remota (Southern,

$10 / \mathrm{S}$

1914)

\section{Polygordiidae}

Polygordius

Iacteus Schneider, 1868

\section{Polynoidae}

\begin{tabular}{|c|c|c|c|c|c|c|c|c|c|}
\hline $\begin{array}{l}\text { Harmothoe } \\
\text { imbricata (Linnaeus, 1767) }\end{array}$ & $40 / \mathrm{W}$ & $30 / A-W$ & - & $40 / W$ & - & $20 / W$ & $10 / A$ & - & 75 \\
\hline Harmothoe sp. & $150 / \mathrm{Sp}$ & $240 / \mathrm{Sp}-\mathrm{S}$ & $20 / S p$ & $130 / \mathrm{W}$ & - & $40 / W$ & $80 / S p$ & $10 / \mathrm{Sp}$ & 87,5 \\
\hline $\begin{array}{l}\text { Malmgrenia } \\
\text { lilianae (Pettibone, 1993) }\end{array}$ & $20 / S p$ & - & $10 / \mathrm{S}$ & - & - & - & - & - & 25 \\
\hline Malmgreniella sp. & $10 / \mathrm{W}$ & $20 / A$ & - & - & - & - & - & - & 25 \\
\hline \multicolumn{10}{|l|}{ Serpulidae } \\
\hline $\begin{array}{l}\text { Pileolaria } \\
\text { militaris Claparède, } 1870\end{array}$ & $210 / S p$ & $1170 / \mathrm{S}$ & - & $290 / \mathrm{W}$ & - & - & $10 / S p$ & - & 50 \\
\hline
\end{tabular}


Tablo 2 (Continued)

Spirobranchus

$100 / 5$

290/W

$10 / \mathrm{S} \quad 230 / \mathrm{W}$

$30 / \mathrm{W}$

62.5

triqueter (Linnaeus, 1758)

Vermiliopsis

10/A

striaticeps (Grube, 1862)

\section{Spionidae}

Aonides

paucibranchiata Southern,

$\begin{array}{cccc}\begin{array}{c}1040 / \\ \mathrm{Sp}\end{array} & 20 / \mathrm{S} & 130 / \mathrm{A} & \begin{array}{c}1200 / \\ \mathrm{Sp}\end{array}\end{array}$

1914

Aonides sp.

$10 / \mathrm{S}$

Prionospio (Minuspio) maciolekae Dagli \& Çinar, $4400 /$ $\mathrm{Sp} \quad \mathrm{Sp}$

$-$

$-$

$-$

\section{1}

Prionospio sp. $30 / \mathrm{W}$ $60 / 5$

460/Sp 6790/W

$50 / \mathrm{A}$

$7480 / A$

3140/A

$30 / \mathrm{Sp}-\mathrm{W}$

\section{Pygospio elegans Claparède,}

1863

Pseudopolydora sp.

Spio decoratus Bobretzky, 1870

Spio cf. filicornis

10/A

$\begin{array}{ccc}20 / \mathrm{S} & 20 / \mathrm{W} & 10 / \mathrm{A} \\ 20 / \mathrm{Sp} & 10 / \mathrm{Sp} & 20 / \mathrm{Sp}\end{array}$

$\begin{array}{ccr}\text { 20/Sp } & 10 / \mathrm{W} & 87.5 \\ 10 / \mathrm{A} & 10 / \mathrm{Sp}-\mathrm{W} & 62.5\end{array}$

Syllidae

Exogone naidina Örsted 1845

\begin{tabular}{|c|c|c|c|c|c|c|c|c|c|}
\hline Myrianida sp. & $10 / \mathrm{Sp}$ & $20 / S p$ & - & - & - & - & - & - & 25 \\
\hline Pionosyllis sp. & - & - & - & - & - & $10 / \mathrm{Sp}$ & - & & 12.5 \\
\hline Salvatoria cf. dolichopoda & $130 / \mathrm{Sp}$ & $80 / S p$ & - & - & - & $10 / \mathrm{Sp}$ & - & - & 37.5 \\
\hline $\begin{array}{l}\text { Salvatoria } \\
\text { clavata (Claparède, 1863) }\end{array}$ & 290/W & $40 / 5 p$ & $60 / S p$ & 20/W & - & $100 / \mathrm{W}$ & - & - & 62.5 \\
\hline Salvatoria sp. & - & $10 / \mathrm{W}$ & - & - & - & - & - & - & 12.5 \\
\hline $\begin{array}{l}\text { Sphaerosyllis taylori Perkins, } \\
1981\end{array}$ & $150 / \mathrm{W}$ & - & $10 / \mathrm{S}$ & $10 / \mathrm{Sp}$ & - & - & $10 / \mathrm{A}$ & $10 / \mathrm{S}$ & 62.5 \\
\hline $\begin{array}{l}\text { Sphaerosyllis thomasi San } \\
\text { Martín, } 1984\end{array}$ & - & - & - & 10/A & - & - & $30 / \mathrm{Sp}$ & - & 25 \\
\hline *Syllis cf. amica & $10 / \mathrm{W}$ & $30 / \mathrm{W}$ & $10 / \mathrm{A}$ & $20 / \mathrm{A}$ & - & - & - & - & 50 \\
\hline Syllis gracilis Grube, 1840 & - & $40 / 5$ & - & - & - & - & - & - & 12.5 \\
\hline Syllis krohnii Ehlers, 1864 & $20 / A$ & - & - & $10 / A-W$ & - & - & $10 / \mathrm{A}$ & - & 37.5 \\
\hline Syllis sp. & $10 / \mathrm{A}$ & $20 / \mathrm{S}$ & $20 / \mathrm{A}$ & $10 / \mathrm{S}$ & - & $40 / \mathrm{A}$ & - & $10 / \mathrm{S}$ & 75 \\
\hline $\begin{array}{l}\text { Trypanosyllis zebra (Grube, } \\
\text { 1860) }\end{array}$ & - & $10 / A-W$ & - & - & - & - & - & - & 12.5 \\
\hline \multicolumn{10}{|l|}{ Terebellidae } \\
\hline $\begin{array}{l}\text { Polycirrus } \\
\text { jubatus Bobretzky, } 1868\end{array}$ & $40 / \mathrm{W}$ & $40 / \mathrm{W}$ & $10 / \mathrm{Sp}$ & $80 / \mathrm{W}$ & - & - & $40 / \mathrm{Sp}$ & - & 62.5 \\
\hline Polycirrus sp. & 20/W & $30 / 5$ & - & $70 / 5$ & - & $10 / \mathrm{A}$ & $10 / \mathrm{A}$ & - & 62.5 \\
\hline Terebella cf. Iapidaria & 10/A & $30 / \mathrm{Sp}$ & - & - & - & - & $60 / A$ & - & 37.5 \\
\hline Terebellidae (sp.) & $30 / \mathrm{A}$ & - & - & - & - & - & - & - & 12.5 \\
\hline \multicolumn{10}{|l|}{ Trichobranchidae } \\
\hline $\begin{array}{l}\text { Terebellides stroemii Sars, } \\
1835\end{array}$ & 170/Sp & $700 / S p$ & $10 / \mathrm{Sp}$ & $60 / \mathrm{W}$ & - & 10/A-Sp-W & $50 / \mathrm{A}$ & - & 75 \\
\hline
\end{tabular}




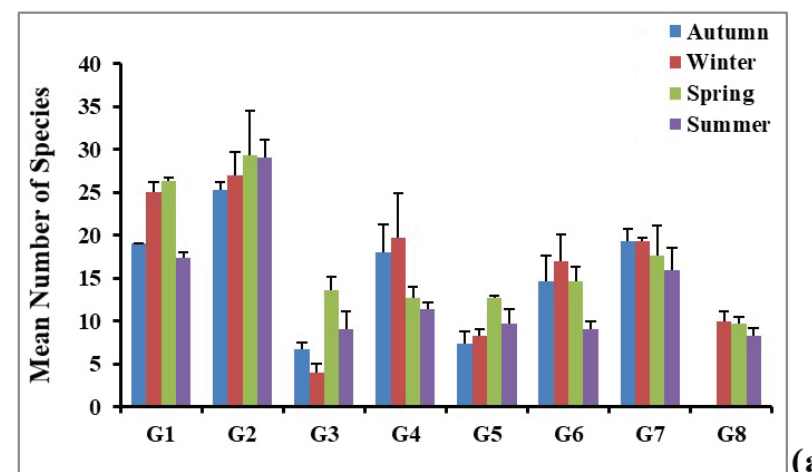

(a)

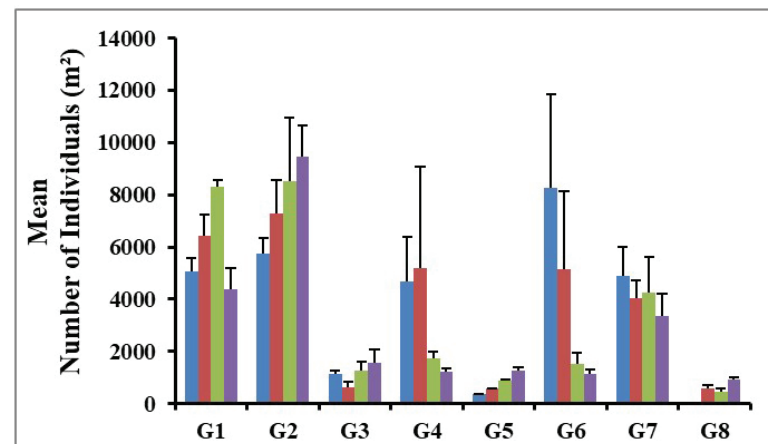

(b)

Figure 2. Seasonal distribution of the mean number of species (a) and individuals $\left(\mathrm{m}^{2}\right)(\mathrm{b})$.

Among dominant and constant species, Prionospio maciolekae was a sensitive species (GI), Micronephthys longicornis, Protodorvillea kefersteini and Spio decoratus were tolerant species (GIII), and Heteromastus filiformis (GV) was a first-order opportunistic species according to the five ecological groups.

The highest mean number of species for all seasons was determined at station G2 (Figure 2a). There was no significant difference between the stations in terms of the average number of individuals; the highest values were determined at G2 in all seasons just except G6 in autumn (Figure 2b). Prionospio maciolekae, Micronephthys longicornis and Protodorvillea kefersteini were the most dominant species in all seasons. The maximum density values for dominant species were $P$. maciolekae with 6,790 ind. $\mathrm{m}^{-2}$ in winter; $M$. longicornis with 4,290 ind. $\mathrm{m}^{-2}$ in winter; P. kefersteini with 4,150 ind. $\mathrm{m}^{-2}$ in autumn.

The highest mean $\mathrm{H}^{\prime}$ value was determined in summer $\left(\mathrm{H}^{\prime}=3.37\right)$ at station G2; whereas the lowest mean value was found at station $\mathrm{G} 3$ in winter $\left(\mathrm{H}^{\prime}=1.25\right)$ (Figure 3a). The highest mean evenness index value was calculated in spring at station $\mathrm{G} 8\left(J^{\prime}=0.85\right)$; and the lowest mean value was found at station $G 4\left(J^{\prime}=0.48\right)$ in autumn (Figure 3b).

\section{DISCUSSION}

The first detailed study on Polychaeta species of soft substratum around the Sinop Peninsula (southern Black Sea) was carried out by Kurt Sahin et al. (5). The present study was per-
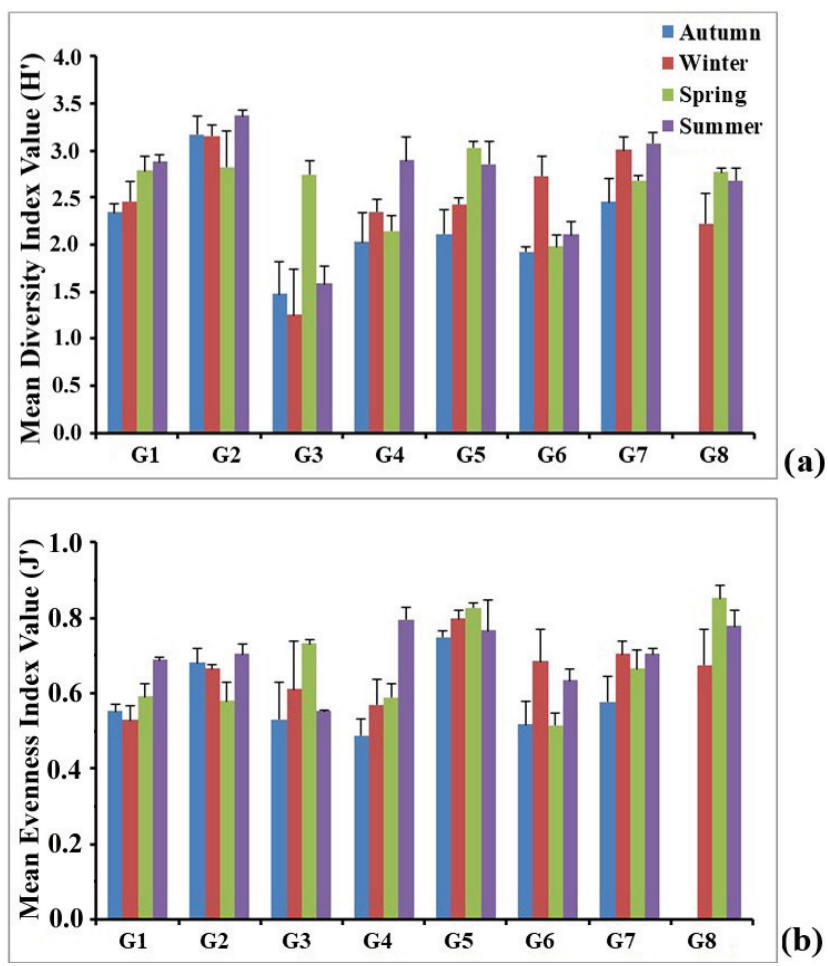

Figure 3. Seasonal distribution of the mean diversity $\left(\mathrm{H}^{\prime}\right)(\mathrm{a})$ and evenness $\left(J^{\prime}\right)(b)$ index values.

formed in the same area, but with different and deeper stations that represent both sides of the peninsula. Kurt-Sahin and colleagues reported $M$. longicornis, P. kefersteini, P. maciolekae, $H$. filiformis and $S$. decoratus as dominant and constant species. We also found these species as dominant and constant in the area. This is probably related to the sediment structure of the area.

Benthic communities were examined in five ecological groups according to their sensitivity to environmental factors. Of the dominant and constant species determined in the present study, Prionospio maciolekae was a sensitive species, Micronephthys longicornis, Protodorvillea kefersteini and Spio decoratus were tolerant species, and Heteromastus filiformis was a first-order opportunistic species. There were no dense populations of species identified as opportunistic in the research area. According to previous studies conducted on the Black Sea coast $(32) ;(5,6,10,28,33)$ and the current research, they are typical species in soft bottoms of the Black Sea.

In the current study, station G2 was represented with the highest value in all seasons in terms of mean number of species (Figure 2a). This is probably related to the sediment structure of station G2. The biotope consists of mud and shell fragments, whose may provide different habitats allowing settlement of diverse species. Station G1 followed station G2 in terms of the number of species in all seasons (Figure 2a). The highest number of species ( 67 species) was presented in spring and the lowest number of species (62 species) was found in summer and winter (Figure 2a). Considering the average number of individ- 
uals, there is significant difference between the seasons (Figure $2 b$ ). As a result of the analysis, it was determined that the average number of individuals was the highest at station $G 2$ in three seasons (maximum density 9,740 ind. $\mathrm{m}^{-2}$ in summer) and the highest density was calculated at station $\mathrm{G} 6\left(2,470\right.$ ind. $\mathrm{m}^{-2}$ in autumn) (Figure 2b).

Syllidae, with 13 species, was the most diverse family in the area, followed by Spionidae, Nereididae and Paraonidae. Kurt Sahin and Çinar (4) stated that most of the species in the Black Sea dwell in soft bottoms. They reported Syllidae and Spionidae (32 and 31 species, respectively) as the most dominant families by means of number of species, followed by Phyllodocidae and Nereididiae. Kurt Sahin et al., (5) reported the most dominant families in the Sinop Peninsula as Syllidae (12 species), Spionidae (8 species) and Paraonidae (7 species).

Spionidae, Nephtyidae and Dorvilleidae were the families with the highest number of individuals and the best representative species were Prionospio maciolekae, Micronephthys longicornis and Protodorvillea kefersteini. Kurt Sahin et al., (5) reported that P. kefersteini has the highest population density $\left(15,125\right.$ ind. $\left.\mathrm{m}^{-2}\right)$ in winter, whereas M. longicornis $\left(10,425\right.$ ind. $\left.\mathrm{m}^{-2}\right)$ in summer. In the present study, the highest population density belonged to P. maciolekae $\left(7,480\right.$ ind. $\left.\mathrm{m}^{-2}\right)$ at station $\mathrm{G} 6$ in the autumn period. Subsequently, M. longicornis $\left(4,290\right.$ ind. $\left.\mathrm{m}^{-2}\right)$ had the highest density at station $\mathrm{G} 1$ in winter, and P. kefersteini (4,150 ind. $\mathrm{m}^{-2}$ ) at station $\mathrm{G} 6$ in autumn.

The highest diversity index value $\left(\mathrm{H}^{\prime}=3.37\right)$ was found in summer and the lowest $\left(H^{\prime}=1.25\right)$ in winter (Figure 3a). The highest evenness index value was calculated as $J^{\prime}=0.85$ in spring and the lowest as $J^{\prime}=0.48$ in autumn (Figure 3b). Kurt Sahin et al., (5) recorded the highest mean diversity index value $\left(\mathrm{H}^{\prime}=3.05\right)$ in summer and the lowest $\left(\mathrm{H}^{\prime}=0.3\right)$ in autumn, and the authors stated that high values were generally seen in summer in the Sinop Peninsula. In the present study, mean evenness index values were high in summer $\left(J^{\prime}=0.88\right)$ and the lowest in winter $\left(J^{\prime}=0.2\right)$.

Polychaete of the soft bottom Turkish coasts of the Mediterranean Sea, the Aegean Sea, and the Sea of Marmara has been well studied, but in the Black Sea, the studies are limited. The first research conducted on Polychaeta biodiversity of Sinop Peninsula was carried out by Cinar and Gönlügür-Demirci (25) that reported 55 polychaete species associated with algae and mussel beds. Gozler et al., (27), reported 9 nereidid species associated with Cystoseira barbata and Mytilaster lineatus facies. Sezgin et al., (34) reported 50 polychaete species in the Anatolian coasts of the Black Sea. Polychaetes from other Black Sea coasts are relatively well known compared with those from Turkey (5). Soft bottom Polychaeta fauna of the Black Sea has been studied in Bulgaria (10), Crimea (12), Romania (13, 15, 16), and the Ukraine (14).

Kurt Sahin et al., (5) reported 76 species from the Sinop Peninsula and Kurt Sahin et al., (6) reported 58 species from the ligneada coast. Finally, Kurt Sahin et al., (7) reported 4 new records for the
Black Sea coast of Turkey and 4 new species for the fauna of the Black Sea.

It is well known that the distribution of soft substratum polychaetes depends on depth, seasonal variables, and sediment structure (35-37). Gambi and Giangrande (38) and Mackie et al., (36) reported that both density and diversity of benthic communities were affected as depth increased. However, it is not possible to make a comparison because there is no significant difference.

\section{CONCLUSION}

The present study shows the current status of the soft substratum polychaetes along the Sinop Peninsula and provides new records for the Black Sea and the Turkish Black Sea coast.

Peer-review: Externally peer-reviewed.

Author Contributions: Conception/Design of study: G.K., M.Ç., Data Acquisition: G.K., M.Ç, S.K.; Data Analysis/Interpretation: G.K., M.Ç, S.K.; Drafting Manuscript: G.K., M.Ç, S.K.; Critical Revision of Manuscript: G.K.; Final Approval and Accountability: G.K.; Technical or Material Support: G.K.; Supervision: G.K.

Conflict of Interest: The authors declare that they have no conflicts of interest to disclose.

Financial Disclosure: There are no funders to report for this submission.

\section{REFERENCES}

1. Appeltans W, Ahyong ST, Anderson G, Angel MV, Artois T, Bailly $\mathrm{N}$ et al. The magnitude of global marine species diversity. Curr Biol 2012; 22: 2189-202.

2. Coll M, Piroddi C, Steenbeek J, Kaschner K, Lasram FBR, Aguzzi J et al. The biodiversity of the Mediterranean Sea: Estimates, patterns and threats. Plos One 2010; 5: 11842.

3. Çinar ME, Dagli E, Kurt Sahin G. Check-list of Annelida from the Coasts of Turkey. Turk J Zool 2014; 38: 734-64.

4. Kurt Sahin G, Çinar ME. A check-list of polychaete species (Annelida: Polychaeta) from the Black Sea. J Black Sea Medit Envir 2012; 18: 10-48.

5. Kurt Sahin G, Daglı E, Sezgin M. Spatial and temporal variations of soft bottom polychaetes of Sinop Peninsula (southern Black Sea) with new records, Turk J Zool 2017a; 41 (1): 89-101.

6. Kurt-Sahin G, Sezgin M, Ünlüer F, Öztürk B, Cavdar E, Daglı E. Macrozoobenthic community structure of İgneada region in Turkey (the southwestern Black Sea). Oceanol Hydrobiol St 2017b; 46: 340-9.

7. Kurt-Sahin G, Çinar ME, Daglı E. New records of polychaetes (Annelida) from the Black Sea. Cah Biol Mar 2019; 60: 153-65.

8. Zaitsev YuP, Alexandrov BG, Berlinsky NA, Zenetos A. Europe's biodiversity -biogeographical regions and seas: The Black Sea an oxygen-poor sea. Environmental issue report Published by EEA (European Environment Agency) Copenhagen 2002.

9. Zaitsev YuP, Alexandrov BG. Black Sea biological diversity Ukraine. Black Sea Environmental Series, 7, United Nations Publishing, 1998.

10. Marinov T. Fauna of Bulgaria. In: BristleWorms (Polychaeta). Vol. 6. Bulgar- skata Akademijana Naukite, Sofia, 1977. 
11. Kiseleva MI. Benthos of the Soft Bottoms of the Black Sea. Naukova Dumka, Kiev, 1981.

12. Revkov NK, Boltacheva NA, Nikolaenko TV, Kolesnikova EA. Zoobenthos Biodiversity over the Soft Bottom in the Crimean coastal zone of the Black Sea. Mar Biol 2002; 42: 561-71.

13. Gomoiu MT, Secrieru D, Paraschiv G, Opreanu P, Puschiaza D. Some remarks on the ecological state of benthic populations recorded during the IAEA'98 Black Sea cruise of "Prof. Vodyanitsky" R/V. Geoecomarina 2004; 9: 12-20.

14. Losovskaya GV. Species and Ecological Diversity and Polychaeta Taxocen in the Northwestern Part of the Black Sea. Hydrobiol J 2005; 41: 3-8.

15. Surugiu V. Inventory of inshore polychaetes from the Romanian coast (Black Sea). Medit Mar Sci 2005; 6, 51-73.

16. Paraschiv GM, Samargiu MD, Sava D. Ecological Study of Vagile Fauna Distribution from the Black Sea Shallow Water at Vama Veche. Agroprint Timisoara 2007; 499-506.

17. Jakubova LI. Features of the biology of Prebosphoric sector of the Black Sea. Trudy Sevastopol'skoj, Biologicheskoj Stantsii, 1948; 6: 274-85.

18. Marinov T. Sur la faune de Polychètes des amas de moules de la mer Noire. Compt Acad Bulg Sci 1959; 12 : 443-6.

19. Dimitrescu E. Contributions à la connaissance des Polychètes de la Mer Noire, spécialement des eaux prébosphoriques. Trav Mus Natl Hist Nat Grigore Antipa 1960; 2: 69-85.

20. Dimitrescu E. Nouvelle contribution à l'étude des Polychètes de la Mer Noire. Trav Mus Natl Hist Nat Grigore Antipa 1962; 3: 61-8.

21. Rullier F. Les annélides polychètes du Bosphore, de la Mer de Marmara et de la Mer Noire, en relation avec celles de la Méditerranée. Rapp Com Int Mer Médit 1963; 17: 161-260.

22. Caspers H. La macrofaune benthique du Bosphore et les problèmes de l'infiltration des éléments Méditerranées dans la mer Noire. Rapp Com Int Mer Médit 1968; 19: 107-15.

23. Gillet $P$, Unsal $M$. Rèsultats de la campagne ocèanographique de "Bilim": annèlides polychètes de la Mer de Marmara, du Bosphore et des règions prèbosphoriques de la Mer Noire. Mèsogèe 2000; 58: 85-91.

24. Uysal A, Yuksek A, Okus E, Yilmaz N. Benthic community structure of the Bosphorus and surrounding area. Water Sci Tech 2002; 46: 37-44.

25. Çinar ME, Gönlügür-Demirci G. Polychaete assemblage on shallow-water benthic habitats along the Sinop Peninsula (Black Sea, Turkey). Cah Biol Mar 2005; 46: 253-63.
26. Agirbas E, Gozler AM, Sahin C, Hacimurtazaoglu N. Doğu Karadeniz'de Dağılım Gösteren Ulva fasiesinin Poliket Faunası. J Fish Sci 2008; 2: 427-31.

27. Gozler AM, Agirbas E, Sahin C. Spatial and temporal distribution of Nereidae (Polychaeta: Annelida) along the coast of Turkish eastern Black Sea in the upper-infralittoral zone. J Anim Vet Adv 2009; 8: 229-34.

28. Kus S, Kurt-Sahin G. Temporal Changes in the Polychaeta (Annelida) Community Associated with Cystoseira Beds of Sinop Peninsula (Southern Black Sea). Turk J Fish Aquat Sc 2016; 16: 61-8.

29. Bellan-Santini D. Contribution a létude des peuplements infralittoraux sur substrat rocheux (Etude qualitative et quantitative de la franch Superiere). Travaux Station Marine d'Endoume, 1969; 63(47): 9-294.

30. Soyer T. Bionomie benthique du plateau continental de la cote catalana Française, III: Les peuplements de Copepodes Harpacticoides (Crustacea). Vie Milieu 1970; 21: 377-511.

31. Çinar ME, Bakir K, Öztürk B, Katagan T, Dagli E, Açik $S$ et al. TUBI (Turkish Benthic Index): A new biotic index for assessing impacts of organic pollution on benthic communities. J Black Sea Medit Env 2015; 21: 135-68.

32. Dimitrescu E. Polychètes marins de la zone littorale Roumaine (1 à 20 m de profondeur). Trav Mus Natl Hist Nat Grigore Antipa 1963; 4: 181-92.

33. Surugiu V. Polychaete Research in the Black Sea. Rom J Aqua Ecol 2011; 1: 101-22.

34. Sezgin M, Kirkim F, Dagli E, Dogan A, Unluoglu A, Katagan T et al. Sublittoral soft-bottom zoobenthic communities and diversity of southern coast of the Black Sea (Turkey). Rapp Comm Int Mer Medit $2010 ; 39: 662$.

35. Tom M, Galil B. The macrobenthic associations of Haifa Bay, Mediterranean coast of Israel. P.S.Z.N.I.: Mar Ecol 1991; 12: 75-86.

36. Mackie ASY, Parmiter C, Tong LKY. Distribution and diversity of Polychaeta in the southern Irish Sea. Bull Mar Sci 1997; 60: 467-81.

37. San Martín G, Parapar J, García FJ, Redondo MS. Quantitative analysis of soft bottoms infaunal macrobenthic polychaetes from South Shetland Islands (Antarctica). Bull Mar Sci 2000; 67: 83-102.

38. Gambi, MC, Giangrande, A. Distribution of soft-bottom polychaetes in two coastal areas of the Tyrrhenian Sea (Italy): structural analysis. Estuar Coast Shelf Sci 1986; 23: 847-62. 